\title{
Portuguese Cucurbita spp. and Citrullus lanatus: Conservation, Evaluation and Breeding
}

\author{
Por:Rocha, FA (Rocha, F. A.) ${ }^{[1]}$; Barata, AM (Barata, A. M.) ${ }^{[1]}$; Quedas, F (Quedas, \\ F.); Lopes, F(Lopes, F.); Marreiros, A (Marreiros, A.); Leitao, J (Leitao, J.) \\ Editado por:Hummer, KE
}

XXVIII INTERNATIONAL HORTICULTURAL CONGRESS ON SCIENCE AND

HORTICULTURE FOR PEOPLE (IHC2010): III INTERNATIONAL SYMPOSIUM ON PLANT GENETIC RESOURCES

Série de livros: Acta Horticulturae

Volume: 918

Páginas: $545-549$

Publicado: 2011

\section{Conferência}

Conferência: 28th International Horticultural Congress on Science and Horticulture for People (IHC) / International Symposium on Plant Protection / 3rd International Symposium on Plant

Genetic Resources

Local: Lisbon, PORTUGAL

Data: AUG 22-27, 2010

\section{Resumo}

Cucurbitaceae is one of the most important families of vascular plants. This family includes 118 genera and 825 species. The five major cucurbit crops are Citrullus lanatus Thumb Mansf. (watermelon), Cucurbita maxima Duchesne (pumpkin), Cucurbita pepo L. (squash), Cucumis sativus L. (cucumber) and Cucumis melo L. (melon). Citrullus lanatus and Cucurbita spp. are very important in the Portuguese agro-ecosystems, associated with maize, beans and cabbage. Due to the importance of Citrullus and Cucurbita spp., the Portuguese National Genebank (BPGV) has done systematic collecting missions in Portugal (Mainland and Madeira Island). Since 2001, BPGV in partnership with other National Institutions, Escola Superior Agraria de Santarem, Direccao Regional de Agricultura e Pescas do Algarve and Universidade do Algarve, has been carrying out activities related to preservation, characterization, evaluation and prebreeding. In Portugal, in BPGV, the Curcubitaceae collection preserved in ex situ conditions (medium and long term) totals 573 accessions. The collection of Citrullus lanatus and Cucurbita spp. has a total of 355 accessions, representing $62 \%$ of the whole collection: (37 of Citrullus lanatus, 19 of Cucurbita ficifolia, 74 of Cucurbita maxima and 224 of Cucurbita pepo). Based upon the diagnosis of the preserved collection, further germplasm collecting missions were recommended in Algarve Region.

AFLP and RAPDs markers were used to check the assignment of accessions to Cucurbita species: C. pepo, C. maxima and C. moshata. The morphological characterization followed the Curcubita spp. and Citrullus descriptors, elaborated by Bioversity International, integrated in the European Cooperative Program for Genetic Resources, Cucurbits Working Group. Characterization data are reported herein. Departing from the most homogeneous accessions of Citrullus lanatus, Cucurbita maxima and C. moschata, three cultivars, one of each species, have already been selected and registered in the National Catalogue of Varieties. 


\section{Palavras-chave}

Palavras-chave de autor:Cucurbita; Citrullus

lanatus; landraces; conservation; evaluation; breeding

Informaçoes sobre autores

Endereço de reprint: Rocha, FA (autor de reprint)

IP Banco Portugues Germoplasma, Inst Nacl Recursos Biol, Braga, Portugal.

Endereços:

[1] IP Banco Portugues Germoplasma, Inst Nacl Recursos Biol, Braga, Portugal

\section{Editor}

INT SOC HORTICULTURAL SCIENCE, PO BOX 500, 3001 LEUVEN 1, BELGIUM

Categorias / Classificaçao

Áreas de pesquisa:Agriculture

Categorias do Web of Science:Horticulture

Informaçoes sobre documentos

Tipo de documento:Proceedings Paper

Idioma:English

Número de acesso: WOS:000313331500068

ISBN:978-90-66055-54-4

ISSN: 0567-7572 